\title{
Pediatric Endocrinology: Global Spread of Type 2 Diabetes Mellitus in Neonatal and Permanent Treatment Using Sulfonylurea Drug Regimen Glibenclamide
}

\section{*Fawzy Elnady, Hanaa A Gouda}

Department of Endocrinology, Brazil.

\author{
*Corresponding Author : Fawzy Elnady, Department of Endocrinology, Brazil. Email: afyusuf@hotmail.com \\ Received date: June 16, 2017;Accepted date : July 19, 2017; Published date: August 10, 2017 \\ Citation for this Article : Fawzy Elnady, Pediatric Endocrinology: Global Spread of Type 2 Diabetes Mellitus in Neonatal And Permanent \\ Treatment Using Sulfonylurea Drug Regimen Glibenclamide. J. Endocrinology and Disorders. Doi: 10.31579/2640-1045/007
}

Copyright : (c) 2017 Fawzy Elnady.This is an open-access article distributed under the terms of the Creative Commons Attribution License, which permits unrestricted use, distribution, and reproduction in any medium, provided the original author and source are credited.

\begin{abstract}
Pediatric endocrinology is a medical subspecialty dealing with disorders of the endocrine glands, such as variations of physical growth and sexual development in childhood, diabetes and many more.

Permanent neonatal diabetes mellitus (PNDM) is a rare form of diabetes characterized by insulin-requiring hyperglycemia that is diagnosed within the first months of life. Type 2 diabetes mellitus is emerging as a new clinical problem within pediatric practice.

\section{Aim of the Study}

An explosion of work over the last decade has produced insight into the multiple hereditary causes of a non-immunological form of diabetes diagnosed most frequently within the first 6 months of life. These studies are providing increased understanding of genes involved in the entire chain of steps that control glucose homeostasis. Neonatal diabetes is now understood to arise from mutations in genes that play critical roles in the development of the pancreas, of $\beta$-cell apoptosis and insulin processing, as well as the regulation of insulin release.

Keywords

Type 2 diabetes mellitus, Children, Clinical manifestation, Screening, Comorbidity, Treatment, and Glibenclamide.
\end{abstract}

\section{Introduction}

Diabetes Mellitus presenting as uncontrolled hyperglycemia during the first 6 months of life is a rare disorder that affects all races and ethnic groups. The majority of the cases present with intrauterine growth retardation (IUGR), failure to thrive, decreased sc fat, and low or undetectable C-peptide levels. This form of hyperglycemia has been termed "early-onset" or neonatal diabetes mellitus (NDM) and is commonly of genetic origin. Because the neonatal period is defined as the first $4 \mathrm{wk}$ of life, whereas diagnosis of these cases extends through 6 months of age, a reviewer pointed out that "congenital diabetes mellitus" is a more valid descriptor for a disorder that is present at birth although not always clinically apparent immediately. However, the term "neonatal diabetes" has become established in the literature; we use the terms interchangeably. Kitselle in 1852 is credited with the first clinical description of the disorder that was present in his so. Temple and Shield (comment on the history of the disease, noting an early report by Ramsey of a low birth weight boy who required insulin to control his transitory diabetes.

\section{Pathophysiology of Type 2 Diabetes Mellitus In Children}

Type 2 diabetes mellitus is a complex metabolic disorder of heterogeneous etiology with social, behavioral, and environmental risk factors unmasking the effects of genetic susceptibility. There is a strong hereditary (likely multigenic) component to the disease, with the role of genetic determinants illustrated when differences in the prevalence of type 2 diabetes mellitus in various racial groups are considered. Although substantial progress in our knowledge of the genetic basis of type 2 diabetes mellitus is taking place, these new discoveries represent but a small proportion of the genetic variation underlying the susceptibility to this disorder. Furthermore-
The recent increases observed in diabetes mellitus prevalence are too quickly to be the result of increased gene frequency and altered gene pool, emphasizing the importance of environmental factors.

Glucose homeostasis depends on the balance between insulin secretion by the pancreatic $\beta$-cells and insulin action. It is well recognized that insulin resistance to insulin-stimulated glucose uptake is a characteristic finding in patients with type 2 diabetes mellitus and impaired glucose metabolism. The evolution from normal to impaired glucose tolerance (IGT) is associated with a worsening of insulin resistance. Impaired glucose tolerance is an intermediate stage in the natural history of type 2 diabetes mellitus and is a predictor of the risk of developing diabetes mellitus and cardiovascular disease. However, there is a high spontaneous conversion rate from IGT to normal glucose tolerance in the next 3 to 5 years in children and adolescents with impaired glucose tolerance. This normalization has been attributed to changes of insulin resistance at end of puberty.

\section{Diagnosis of Neonatal Diabetes Mellitus}

Diagnosis of "early-onset" diabetes can occur within the first days or months of life with presentation of hyperglycemia. In rare cases there are neural complications. The time of presentation is variable, and a potential diagnostic problem is the differentiation of a monogenic cause $v s$. autoimmune type 1 diabetes in these early-onset children. Although seroconversion has been reported in some patients with long-standing congenital diabetes the available data strongly support the argument that cases of diabetes diagnosed before 6 months of age are probably of monogenic origin and thus are candidates for genetic screening.

\section{Monitoring And Treatment Of Complications Of Type} 2 Diabetes Mellitus In Children

Since microvascular complications of type 2 diabetes mellitus like retinopathy and nephropathy already occur in children, dilated eye examinations should be performed. 
Screening for microalbuminuria should also be performed yearly. Angiotensin converting enzyme (ACE) inhibitors are the agents of choice in children with microalbuminuria. It is unclear whether foot examinations are important in children. Control of hypertension in children with type 2 diabetes mellitus is mandatory]. If normotension is not achieved by ACE inhibitors, combination therapy with ablockers, calcium antagonists or low-dose diuretics may be needed. Testing for and treating lipid abnormalities are necessary to avoid macrovascular diseases.

\section{Etiology of Transient Neonatal Diabetes Mellitus}

The hyperglycemia characteristic of TNDM is the result of reduced or absent insulin output during the fetal period that extends for a variable time into postnatal life. The genetic origin for more than $90 \%$ of TNDM cases has been established. Recent work suggests that the deficit in insulin output can arise either from delayed maturation of pancreatic islets and $\beta$-cells as a consequence of the altered expression of imprinted genes on chromosome 6 or from $\beta$-cell dysfunction that impairs insulin secretion. In the first case, islets and $\beta$-cells are poorly developed with reduced or absent insulin; in the latter instance, insulin is present but glucose sensing is defective, thus abrogating insulin release. In either case, reduced fetal insulin, acting as a growth factor, is expected to slow fetal growth.

\section{Sulfonylureas In Diabetes Management}

An ideal anti-diabetic should confer glycaemic control, with lower risk of side effects, while providing inexpensive ease of use. SUs are wellestablished glucose-lowering drugs, with insulinotropic action on pancreatic $\beta$-cells. Since the introduction of tolbutamide in 1956 newer SUs have been developed, broadly classified based on their affinity to bind with sulfonylurea receptor (SUR) proteins.The availability of modern SUs (glimepiride, glipizide, gliclazide MR and gliclazide modified release [MR]) with fewer side-effects and better efficacy [have contributed to their popularity.Although the mechanism of action of SUs is well understood, their safety has been a matter of debate. Recent reviews and retrospective analyses suggest that SUs may cause hypoglycaemia and weight gain. In addition, certain SUs are believed to accelerate $\beta$-cell apoptosis, increase the risk of ischemic complications, and contribute to non-fatal cardiovascular (CV) outcomes and all-cause mortality. The present consensus attempts to address their safety issues.

\section{Methods}

The blood glucose of all 30768 patients who attended the emergency department of the region's central hospital was determined to detect severe hypoglycaemia, which was defined by the requirement for intravenous glucose or glucagon injection and blood glucose value of $<2.8 \mathrm{mmol} / 1$. Additionally, $6631 / 7804$ patients $(85 \%)$ attended to by the emergency medical services received a blood glucose test at the emergency site. The regional prescribing frequency of both sulphonylureas was determined by an independent external institute.

\section{Results}

Despite being prescribed more frequently than glibenclamide (6976 vs 6789 person- years), one episode occurred with a combination of the two preparations. The incidence of severe hypoglycaemia was 0.86/1000 person- years for glimepiride and 5.6/1000 person- years for glibenclamide. The characteristics of the 45 patients who presented with sulphonylurea- associated hypoglycaemia were as follows: mean age 79 years $(95 \%$ CI $75.2 ; 82.6)$; glycosylated haemoglobin $5.4 \%$ (95\% CI 5.1; 5.7); impaired renal function in $62 \%$.

\section{Conclusion}

Type 2 diabetes mellitus is still rare in childhood and, but recent reports indicate an increasing prevalence around the world possibly due to increasing prevalence of obesity in children.This is particularly the case in the United States but has also been reported in other countries in Asian and Europe.
It is becoming increasingly clear that obese children and with clinical signs of insulin resistance dyslipidemia, hypertension, PCOS) or relatives with type 2 diabetes mellitus or of particular ethnic populations (Asian, American Indian, Africa-Americans, Hispanics) above the age of 10 years should be screened for type 2 diabetes mellitus. Prevention and treatment of type 2 diabetes mellitus should become one of the prime targets of public health intervention programs. Much more attention should be given to the prevention and development of preventive strategies early in life. Finally, and most importantly, public awareness of the increasing health burden and economic dimension of the childhood obesity epidemic is of importance. Physicians should make the public aware of both the childhood obesity epidemic and its serious consequences, not least type 2 diabetes mellitus.

\section{References}

1. Arslanian S. Type 2 diabetes in children: clinical aspects and risk factors. Horm Res. 2002;57 Suppl 1:19-28.

2. Rodriguez BL, Fujimoto WY, Mayer-Davis EJ, Imperatore G, Williams DE, Bell RA, Wadwa RP, Palla SL, Liu LL, Kershnar A, et al. Prevalence of cardiovascular disease risk factors in U.S. children and adolescents with diabetes: the SEARCH for diabetes in youth study. Diabetes Care. 2006;29:1891-1896.

3. Reinehr T. Clinical presentation of type 2 diabetes mellitus in children and adolescents. Int J Obes (Lond) 2005;29 Suppl 2:S105-S110.

4. Awa WL, Boehm BO, Rosinger S, Achenbach P, Ziegler AG, Krause S, Meissner T, Wiegand S, Reinehr T, Kapellen T, et al. HLA-typing, clinical, and immunological characterization of youth with type 2 diabetes mellitus phenotype from the German/Austrian DPV database. Pediatr Diabetes. 2013;14:562-574.

5. Schober E, Waldhoer T, Rami B, Hofer S. Incidence and time trend of type 1 and type 2 diabetes in Austrian children 1999-2007. J Pediatr. 2009;155:190-193.e1.

6. Drake AJ, Smith A, Betts PR, Crowne EC, Shield JP. Type 2 diabetes in obese white children. Arch Dis Child. 2002;86:207208.

7. Type 2 diabetes in children and adolescents. American Diabetes Association. Diabetes Care. 2000;23:381-389.

8. Schober E, Holl RW, Grabert M, Thon A, Rami B, Kapellen T, Seewi O, Reinehr T. Diabetes mellitus type 2 in childhood and adolescence in Germany and parts of Austria. Eur J Pediatr. 2005; 164:705-707.

9. Springer SC, Silverstein J, Copeland K, Moore KR, Prazar GE, Raymer T, Shiffman RN, Thaker VV, Anderson M, Spann SJ, et al. Management of type 2 diabetes mellitus in children and adolescents. Pediatrics. 2013;131:e648-e664.

10. Rosenbloom AL, Silverstein JH, Amemiya S, Zeitler P, Klingensmith GJ. ISPAD Clinical Practice Consensus Guidelines 2006-2007. Type 2 diabetes mellitus in the child and adolescent. Pediatr Diabetes. 2008;9:512-526.

11. Arslanian SA. Type 2 diabetes mellitus in children: pathophysiology and risk factors. J Pediatr Endocrinol Metab. 2000;13 Suppl 6:1385-1394.

12. Lobstein T, Frelut ML. Prevalence of overweight among children in Europe. Obes Rev. 2003;4:195-200.

13. Han JC, Lawlor DA, Kimm SY. Childhood obesity. Lancet. 2010;375:1737-1748.

14. Moss A, Klenk J, Simon K, Thaiss H, Reinehr T, Wabitsch M. Declining prevalence rates for overweight and obesity in German children starting school. Eur J Pediatr. 2012;171:289-299.

15. May AL, Kuklina EV, Yoon PW. Prevalence of cardiovascular disease risk factors among US adolescents, 1999-2008. Pediatrics. 2012;129:1035-1041.

16. Kiess W, Böttner A, Raile K, Kapellen T, Müller G, Galler A, Paschke R, Wabitsch M. Type 2 diabetes mellitus in children and adolescents: a review from a European perspective. Horm Res. 2003;59 Suppl 1:77-84.

17. Florez JC. Clinical review: the genetics of type 2 diabetes: a realistic appraisal in 2008. J Clin Endocrinol Metab. 2008;93:4633-4642. 
18. American Diabetes Association. Diagnosis and classification of diabetes mellitus. Diabetes Care. 2013;36 Suppl 1:S67-S74.

19. Kleber M, Lass N, Papcke S, Wabitsch M, Reinehr T. One-year follow-up of untreated obese white children and adolescents with impaired glucose tolerance: high conversion rate to normal glucose tolerance. Diabet Med. 2010;27:516-521.

20. Kleber M, deSousa G, Papcke S, Wabitsch M, Reinehr T. Impaired glucose tolerance in obese white children and adolescents: three to five year follow-up in untreated patients. Exp Clin Endocrinol Diabetes. 2011;119:172-176.
21. Pinhas-Hamiel O, Lerner-Geva L, Copperman NM, Jacobson MS. Lipid and insulin levels in obese children: changes with age and puberty. Obesity (Silver Spring) 2007;15:2825-2831.

22. Weiss R, Dziura J, Burgert TS, Tamborlane WV, Taksali SE, Yeckel CW, Allen K, Lopes M, Savoye M, Morrison J, et al. Obesity and the metabolic syndrome in children and adolescents. N Engl J Med. 2004;350:2362-2374. 